Article

\title{
Assessment of Two Sweet Orange Cultivars Grafted on Selected Rootstocks Grown on an Inceptisol in Puerto Rico
}

\author{
Rebecca Tirado-Corbalá ${ }^{1, * \mathbb{C}}$, Alejandro Segarra-Carmona ${ }^{1}$, Manuel Matos-Rodríguez ${ }^{2}$, \\ Dania Rivera-Ocasio ${ }^{1}$, Consuelo Estévez de Jensen ${ }^{1}$ and Jeniffer Pagán ${ }^{1}$ \\ 1 Agro-Environmental Sciences Department, University of Puerto Rico-Mayagüez, Box 9000, \\ Mayagüez, PR 00681, USA; alejandro.segarra@upr.edu (A.S.-C.); dania.rivera@upr.edu (D.R.-O.); \\ consuelo.estevez@upr.edu (C.E.d.J.); jeniffer.pagan@upr.edu (J.P.) \\ 2 United States Department of Agriculture, Natural Resources Conservation Service, Caribbean Area Office, \\ Hato Rey, PR 00918-4123, USA; manuel.matos@usda.gov \\ * Correspondence: rebecca.tirado@upr.edu or rebeccatiradocorbala@gmail.com; Tel.: +1-(787)-370-9179
}

Received: 10 March 2020; Accepted: 12 May 2020; Published: 18 May 2020

\begin{abstract}
Sweet oranges in Puerto Rico and other citrus-producing areas in the world have been greatly affected by the Huanglongbing disease (HLB). Historically, most of Puerto Rico's citrus production has been located from 0-600 $\mathrm{m}$ above sea level, where fruit acquire a desirable color and flavor due to climatic conditions. However, higher populations of the disease vector Diaphorina citri Kuwayama have been reported at these elevations in Puerto Rico. Although only $6.4 \%$ of the land area is located above $600 \mathrm{~m}$, it is composed mainly of environmentally sensitive or non-arable land where Inceptisols are the dominant soil order. For that reason, 'Marr's Early' and 'Pera' sweet orange (Citrus sinensis) scions grafted on 'Carrizo', 'HRS 802', and 'HRS 812' rootstocks were planted in Alonso clay series Inceptisol (Oxic Humudepts) at $649 \mathrm{~m}$ in 2010. Tree growth parameters (height, diameter, canopy volume) and yield efficiency were measured. Fruit quality was determined from juice content $(\%)$, total soluble solids [ $\left.{ }^{\circ} \mathrm{Brix}\right]$, and $\mathrm{pH}$. Leaf tissue analyses showed an optimum range for $\mathrm{Ca}, \mathrm{Mg}, \mathrm{Na}, \mathrm{P}, \mathrm{B}, \mathrm{Cu}$, and $\mathrm{Zn}$, an indicator of tree health. A few were high (i.e., $\mathrm{N}$ and $\mathrm{P}$ ) or in excess (i.e., $\mathrm{Fe}$ ), but no clear connection to specific scions or rootstocks could be established. Tree height, tree diameter, fruit production, and juice content were higher in both sweet oranges grafted on 'HRS 802' compared with those on 'HRS 812' and 'Carrizo'. Therefore, 'HRS 802' rootstock can be recommended to local farmers growing sweet oranges in Alonso series soil.
\end{abstract}

Keywords: Inceptisols; Huanglongbing; 'Marr's Early' sweet orange; 'Pera' sweet orange; rootstocks; scions

\section{Introduction}

Worldwide, sweet oranges [Citrus sinensis (L.) Osb.] are an important staple fruit, used for fresh consumption and for processing (i.e., juice, canning). In Puerto Rico, they are grown primarily in the middle- to high-elevation districts (100-800 $\mathrm{m}$ above sea level), where fruit tends to acquire a desirable color and flavor due to higher temperatures during the day, lower temperatures at night, and adequate rainfall and irrigation. In 2012, the island's citrus industry was ranked second among fruit commodities, with over 7000 ha planted on 2800 farms ( 700 producers). Between 2013 and 2014, the most recent years when detailed data are available, citrus ranked as third most valuable crop, with a net value of $\$ 6$ million as reported by the Department of Agriculture of Puerto Rico (DAPR) [1,2]. However, in 2009, citrus greening or the Huanglongbing (HLB) disease (Candidatus Liberibacter asiaticus (CLas) was first reported in Puerto Rico [3,4], and as a result, the island experienced a 39\% reduction in citrus production (2556 tons to 1557 tons) in citrus production by 2015 [5]. 
The introduction of HLB has forced most of the 700 producers on the island to abandon their land and switch to alternate crops, such as coffee or plantains, and most have faced high economic losses [6]. Citrus trees infected with HLB show characteristic leaf mottling, yellow shoots, acidic and deformed fruit, shortened production life span, branch dieback, and invariably tree death [3,4]. The causal bacterium is vectored by the Asian citrus psyllid (ACP, Diaphorina citri Kuwayama (Hemiptera: Liviidae)) [7]. The severity of HLB infections appears to be more severe in orange and mandarin orchards [6], especially in low and middle elevations $(0-600 \mathrm{~m})$. Perhaps the best explanation for this was provided by Jenkins et al. [8], who established that ACP populations decline with elevation, finding no vectors at elevations over $600 \mathrm{~m}$ in Puerto Rico. These authors concluded that the lower ACP abundance at higher elevations results in lower HLB incidence. Historically, most of Puerto Rico's citrus production was located below this elevation. Thus, the true impact of HLB on Puerto Rico's citrus production is grasped when it is understood that, of the island's land-area of 3.4 million ha, approximately 213,900 ha $(6.4 \%)$ remains above $600 \mathrm{~m}$, and most of that is composed of environmentally sensitive or non-arable land $[9,10]$.

In these environmentally sensitive areas above $600 \mathrm{~m}$, there are six of the 10 soil Orders (Figure 1) present on the island, with the Inceptisols being one of the most common [9]. Inceptisols cover about 27,316 ha of the mountain region above $600 \mathrm{~m}$ (under an udic moisture regime), and most are found on steep slopes (20\% to 60\%). For example, in Adjuntas, a historically important citrus-producing municipality in Puerto Rico, a common Inceptisol is the Alonso Clay series (Oxic Humudepts). Of 972 ha of the Alonso clay present in the Adjuntas, 281 ha are found with 20\%-40\% slopes, and 691 in steeper slopes $(40 \%-60 \%)$.

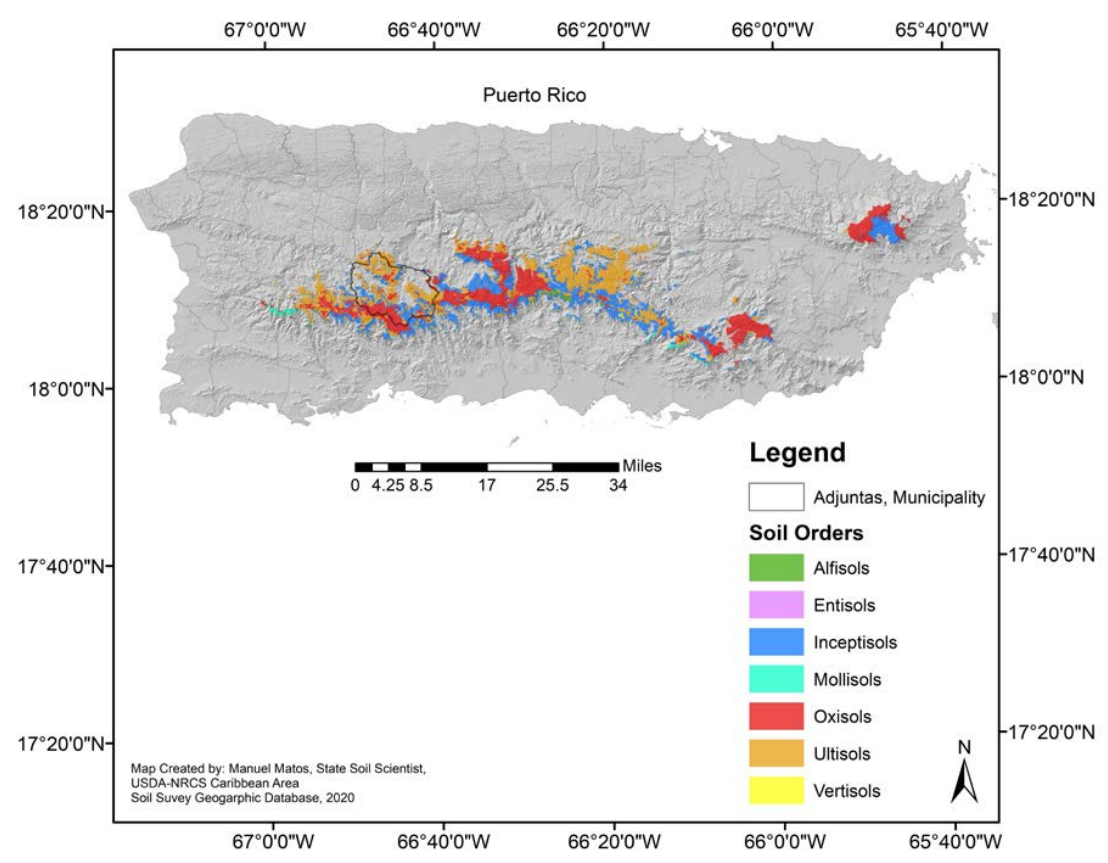

Figure 1. Land-area above $600 \mathrm{~m}$ in Puerto Rico and its predominant soil orders (Data and Map generated by Manuel Matos-Rodríguez, State Soil Scientist, USDA-NRCS Caribbean Area, 2019). This figure cannot be used in a publication before requesting authorization of Manuel Matos-Rodríguez.

At the higher elevations ( $>600 \mathrm{~m})$, two important citrus diseases are found: Citrus tristeza virus (CTV) (genus Closterovirus) and Phytophthora foot and root rot (Phytophthora spp.) [11]. Of these, CTV is possibly the most prevalent and serious disease of citrus in the higher districts in Puerto Rico [12-16]. After CTV's introduction almost 30 years ago, most producers switched to 'Cleopatra' mandarin rootstock (Citrus reshni Hort. Ex Tan) due to its satisfactory tolerance to CTV. However, through the years, 'Cleopatra' rootstocks have showed susceptibility to Phytophthora citrophthora (R.E. Sm. \& E.H. Sm.) Leonian, with increasingly observed tree mortality [17]. 
Thus, the new circumstances faced by citrus producers in Puerto Rico increasingly require the need for evaluating novel scion-rootstock combinations, using new promising sweet orange cultivars, which are capable of thriving at higher elevations $(>600 \mathrm{~m})$, and which are tolerant to various pests and disease combinations. Therefore, our objective here was to evaluate two promising sweet orange varieties ('Marr's Early' and 'Pera') grafted on three selected rootstocks grown in Puerto Rico's mountainous region. We were particularly interested in determining the effect of each scion-rootstock combination on tree growth variables, fruit yield, and mineral nutrient absorption.

\section{Materials and Methods}

\subsection{The Experimental Area}

The experimental orchard was planted in 2010 in the Agricultural Experiment Substation (AES) at Adjuntas, which is located in the Central Mountain region of the island of Puerto Rico $\left(18.1735^{\circ} \mathrm{N}\right.$ and $66.7989^{\circ} \mathrm{W}$ ) at $649 \mathrm{~m}$ above sea level. This citrus orchard was established on an Alonso clay series (very-fine, parasesquic, isohyperthermic, oxic humudepts) soil, an Inceptisol common in Adjuntas [10], and at an elevation slightly over $600 \mathrm{~m}$ above sea level (Figures 1 and 2). The annual average precipitation is $1893 \mathrm{~mm}$, where the rainy months are May, and August-October, and the driest months are December-March and June-July. The maximum average temperature is $28^{\circ} \mathrm{C}$ and the minimum average temperature is $10^{\circ} \mathrm{C}$.

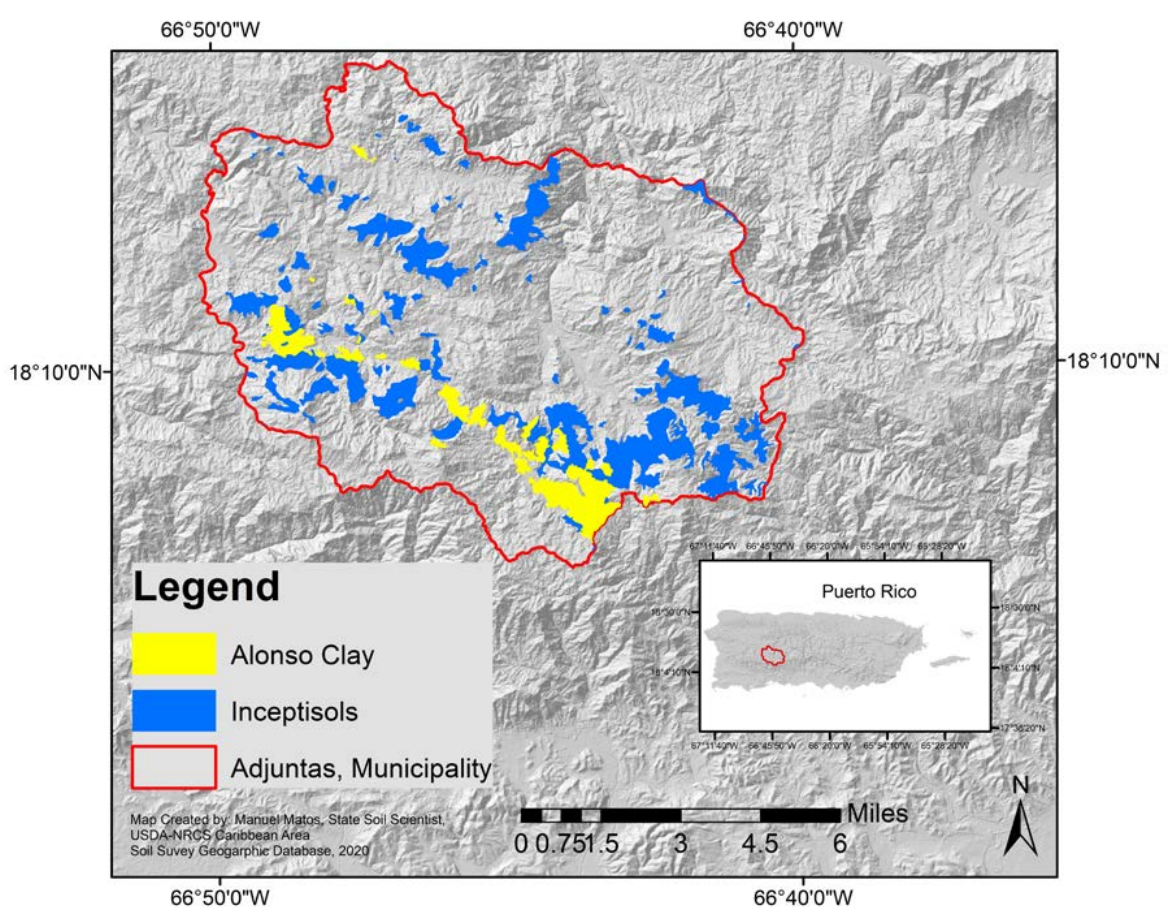

Figure 2. Experimental orchard location, and location of Inceptisols, including Alonso clay (Data and Map generated by Manuel Matos-Rodríguez, State Soil Scientist, USDA-NRCS Caribbean Area, 2019). This figure cannot be used in a publication before requesting authorization of Manuel Matos-Rodríguez.

\subsection{Scion-Rootstock Combinations, Disease Testing, and Orchard Management}

'Marr's Early' and 'Pera' sweet orange [Citrus sinensis (L.) Osb.] scions were grafted on three different citrus rootstocks: (1) 'Carrizo' citrange [C. sinensis $\times$ Poncirus trifoliata (L.) Raf.]; (2) 'HRS 802' [Citrus grandis (L.) Osb. 'Siamese pummelo' $\times$ P. trifoliata 'Gotha Road' trifoliate orange], and (3) 'HRS 812'.

[Sunki mandarin, Citrus reticulata $\times$ P. trifoliata (L.) Raf.]. 'Pera' sweet orange is one of the principal varieties in Brazil and Florida (USA) for processing purposes [7]. Rootstock trees were produced 
from seeds and later grafted with the scions in greenhouses protected with anti-insect screen mesh $(0.24 \mathrm{~mm} \times 0.75 \mathrm{~mm})$. At planting time, all trees tested free of Candidatus Liberibacter asiaticus by DNA amplification using conventional polymerase chain reaction (PCR) [18] with primers OI1 and OI2c (IDT Technologies, Coralville, IA, USA). For the PCR analyses, three leaves from each tree were collected, and a control for each positive and negative sample was included. Testing for citrus tristeza virus (CTV) was conducted using an Enzyme-Linked Immunosorbent Assay (ELISA) (AGDIA, Elkhart, IN, USA) following the company protocols. No further HLB or CTV tests were performed in the field during the research period (2010-2016).

The experimental orchard was established as a Randomized Complete Block Design (RCBD) with three replicates of each scion-rootstock combination. Trees were sown at a distance of $4.6 \mathrm{by} 6.1 \mathrm{~m}$, each experimental plot containing two trees. A supplementary drip irrigation system was installed and used as needed. At planting time (2010), each tree received four (3 g per tablet/A.M. Leonard Horticultural Tool and Supply Co., Piqua, OH, USA) tablets of slow-release fertilizer (14-4-6). During 2011 , each tree received $0.23 \mathrm{~kg}$ 12-6-6 controlled-release fertilizer four times a year. In 2012, each tree received $0.45 \mathrm{~kg}$ of 12-6-6 controlled-release fertilizer four times (every three months). Thereafter until 2016, each tree received $1.4 \mathrm{kgs}$ of 12-6-6 four times per year. Trees also received a monthly supplemental foliar application mix consisting of nitrogen $(\mathrm{N})(30-0-0)$, Phosphite ${ }^{\circledR}(0-29-26)$, Keyplex ${ }^{\circledR}$ 350 DP, and a biological fungicide (Companion $\left.{ }^{\circledR}\right)$. The control of insect vectors and other pests was achieved through applications of the systemic insecticide Admire Pro ${ }^{\circledR}$ (active ingredient Imidacloprid) every two months at rates of 7-14 fl. oz. per acre. Glyphosate (Roundup ${ }^{\circledR}$ ) was applied for weed control when needed at $0.75-1.5 \mathrm{lbs}$ AI per acre, depending on the stage of maturity of the weed stage.

\subsection{Soil Fertility, Tree Growth, Leaf Nutrient Analysis, and Yield}

To determine soil fertility, composite soil samples were collected from the upper $20 \mathrm{~cm}$ around each sweet orange scion/rootstock combination, using a $7.62 \mathrm{~cm}$ bucket auger in April 2016. Soil pH was measured in a 1:1 (v:v) soil-water mixture [19]. Exchangeable calcium $\left(\mathrm{Ca}^{2+}\right)$, magnesium $\left(\mathrm{Mg}^{2+}\right)$, sodium $\left(\mathrm{Na}^{+}\right)$, and potassium $\left(\mathrm{K}^{+}\right)$were extracted using $1 \mathrm{M} \mathrm{NH}_{4} \mathrm{OAc}$ [20] and available phosphorous (P) by Olsen extracts. Organic matter (OM) was determined by loss on ignition. Total S was determined via inductively coupled plasma spectrometry (ICP) (Teledyne Leeman Labs Prodigy Dual, Hudson, $\mathrm{NH})$ after perchloric acid digestion [21,22]. Nitrate $\left(\mathrm{NO}_{3}-\mathrm{N}\right)$ content (1:1 soil: distilled (DI) water) was determined by using a Nitrate-Nitrite Astoria Pacific 2 analyzer (Portland, OR). In addition, citrus leaf tissue samples, taken from the central part of trees at four coordinates-north, south, east, and west, were collected simultaneously from each scion-rootstock combination and replicate, and analyzed for $\mathrm{N}, \mathrm{Ca}, \mathrm{Mg}, \mathrm{P}, \mathrm{K}$, manganese $(\mathrm{Mn})$, iron (Fe), copper $(\mathrm{Cu})$, boron (B), aluminum (Al), $\mathrm{Na}$, and zinc $(\mathrm{Zn})$ were extracted using Mehlich 3.

Tree growth parameters, including height, diameter, canopy volume, and yield were measured to determine citrus crop performance. Growth parameters were measured in 2015 and 2016. Tree height and diameter were measured using a telescoping-measuring pole, and total canopy volume $(\mathrm{CV})$ was calculated using the Fallani and Mousavi [23] equation: $C V=0.524 \times$ tree height $(\mathrm{m}) \times$ tree square diameter $\left(\mathrm{m}^{2}\right)$. The yield efficiency was calculated using the total average fruit number divided by $\mathrm{CV}$. Fruit yield variables, fruit number, and size, were totaled for each year. Production was quantified several times in 2013, and thereafter, assessed from January to February each year. Fruit quality (2014-2016) was determined from the juice content (\%), total soluble solids [ ${ }^{\circ}$ Brix], and $\mathrm{pH}$.

\subsection{Statistical Analysis}

Analysis of variance (ANOVA), followed by means separation using Tukey's Honestly Significant Difference test at $\alpha<0.05$ for an RCBD design was used to compare soil fertility, tissue analyses, and tree and yield variables from different scion-rootstock combinations. Statistical analysis was undertaken using JMP Version 10 (SAS Institute, Cary, NC, USA). 


\section{Results}

\subsection{Soil Chemical Properties}

Soil $\mathrm{pH}, \mathrm{Ca}$, and $\mathrm{S}$ concentrations varied significantly by rootstock in both sweet orange varieties. Soil collected from 'HRS 802' rootstocks had higher $\mathrm{pH}$ and $\mathrm{Ca}$ concentrations than 'Carrizo' or 'HRS 812' (Table 1). However, higher concentrations of $S$ were found in 'Carrizo' and 'HRS 812' as compared with 'HRS 802' rootstocks. $\mathrm{NO}_{3}-\mathrm{N}$ was statistically different only in soil samples collected from 'Pera' sweet orange plots, with higher concentrations in 'HRS 812' rootstock than from 'Carrizo' or 'HRS 802' soil samples. No statistically significant differences were found in the rest of the studied variables (Table 1).

Table 1. Soil Nutrients in 2016 of two sweet orange cultivars growing on Alonso Clay series soil grafted on three different rootstocks at the Agricultural Experiment Station of Adjuntas, Puerto Rico.

\begin{tabular}{|c|c|c|c|c|c|c|c|c|c|c|}
\hline \multirow{2}{*}{ Scion } & \multirow{2}{*}{ Rootstocks } & $\mathrm{OM}^{\mathrm{z}}$ & $\mathrm{pH}$ & $\mathrm{Ca}$ & $\mathbf{K}$ & $\mathrm{Mg}$ & $\mathrm{Na}$ & $\mathbf{P}$ & $\mathbf{S}$ & $\mathrm{NO}_{3}-\mathrm{N}$ \\
\hline & & - -\%- - & - -1:1- - & \multicolumn{6}{|c|}{ - . - - - - - } & - -ppm- - \\
\hline \multirow{4}{*}{$\begin{array}{c}\text { ‘Marr's } \\
\text { Early' }\end{array}$} & 'Carrizo' & 5.07 & $4.63 \mathrm{~b}^{\mathrm{y}}$ & $1353 \mathrm{~b}$ & 231 & 451 & 21.3 & 26.7 & $50.7 \mathrm{a}$ & 25.0 \\
\hline & 'HRS 802' & 5.3 & $5.2 \mathrm{a}$ & $2123 \mathrm{a}$ & 210 & 607 & 31.3 & 16.3 & $33.7 \mathrm{~b}$ & 18.3 \\
\hline & 'HRS 812' & 5.1 & $4.7 \mathrm{~b}$ & $1673 \mathrm{~b}$ & 229 & 541 & 24.0 & 37.3 & $52.0 \mathrm{a}$ & 27.7 \\
\hline & $\operatorname{Pr}>F$ & 0.35 & 0.028 & 0.045 & 0.97 & 0.71 & 0.42 & 0.17 & 0.038 & 0.59 \\
\hline \multirow{4}{*}{ 'Pera' } & 'Carrizo' & 5.93 & $4.80 \mathrm{~b}$ & $1977 \mathrm{~b}$ & 208 & 516 & 29.7 & 35.0 & $35.0 \mathrm{a}$ & $15.0 \mathrm{~b}$ \\
\hline & 'HRS 802' & 6.0 & $5.37 \mathrm{a}$ & 2477 a & 174 & 672 & 32.7 & 11.3 & $19.0 \mathrm{~b}$ & $10.7 \mathrm{~b}$ \\
\hline & 'HRS 812' & 5.53 & $4.87 \mathrm{~b}$ & $2043 b$ & 242 & 548 & 24.0 & 31.7 & $35.0 \mathrm{a}$ & $25.3 \mathrm{a}$ \\
\hline & $\operatorname{Pr}>F$ & 0.26 & 0.02 & 0.05 & 0.53 & 0.33 & 0.11 & 0.39 & 0.043 & 0.05 \\
\hline
\end{tabular}

${ }^{\mathrm{z}} \mathrm{OM}=$ organic matter, $\mathrm{Ca}=$ exchangeable calcium, $\mathrm{K}=$ exchangeable potassium, $\mathrm{Mg}=$ exchangeable magnesium, $\mathrm{Na}=$ exchangeable sodium, $\mathrm{P}=$ available phosphorous, $\mathrm{S}=$ total Sulfur, and $\mathrm{NO}_{3}-\mathrm{N}=$ nitrate. ${ }^{\mathrm{y}}$ Means followed by the same letter or no letters in a column within each scion are not significantly different by Tukey's test at $\alpha<0.05$.

\subsection{Leaf Tissue Macronutrient and Trace Element Concentrations}

Leaf tissue $\mathrm{K}$ and $\mathrm{S}$ concentrations varied significantly by rootstock in both orange varieties (Table 2). Both cultivars grafted on 'HRS 812' rootstock had higher concentrations of K than those on 'Carrizo' or 'HRS 802'. 'Carrizo' trees showed higher S concentrations when compared with either 'HRS 802' or 'HRS 812'. No statistically significant differences were found in N, Ca, Mg Na, or P.

Table 2. Mean concentrations of leaf tissue nutrients in 2016 of two sweet orange cultivars growing in Alonso clay series soil grafted on three different rootstocks at the Agricultural Experiment Station of Adjuntas, Puerto Rico.

\begin{tabular}{|c|c|c|c|c|c|c|c|c|}
\hline Scion & Rootstocks & $\mathbf{N}^{\mathbf{z}}$ & Ca & $\mathbf{K}$ & Mg & $\mathrm{Na}$ & $\mathbf{P}$ & $\mathbf{S}$ \\
\hline & & $---\%$ & \multicolumn{6}{|c|}{ 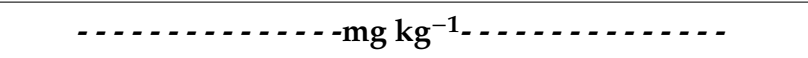 } \\
\hline \multirow{4}{*}{$\begin{array}{c}\text { 'Marr's } \\
\text { Early' }\end{array}$} & 'Carrizo' & 2.74 & 3.33 & $1.54 \mathrm{a}^{\mathrm{y}}$ & 0.44 & 0.08 & 0.17 & $0.37 \mathrm{a}$ \\
\hline & ‘HRS 802’ & 2.60 & 3.77 & $1.57 \mathrm{a}$ & 0.43 & 0.07 & $0.23^{\mathrm{H}}$ & $0.30 \mathrm{~b}$ \\
\hline & 'HRS 812' & $2.95^{\mathrm{H}}$ & 3.20 & $1.26 \mathrm{~b}$ & 0.42 & 0.06 & $0.21^{\mathrm{H}}$ & $0.31 \mathrm{~b}$ \\
\hline & $\operatorname{Pr}>F$ & 0.21 & 0.38 & 0.017 & 0.90 & 0.24 & 0.46 & 0.029 \\
\hline \multirow{4}{*}{ ‘Pera' } & 'Carrizo' & 2.49 & 3.34 & $1.17 \mathrm{a}$ & 0.41 & 0.07 & 0.17 & $0.35 \mathrm{a}$ \\
\hline & 'HRS 802' & 2.49 & 4.25 & $1.30 \mathrm{a}$ & 0.46 & 0.06 & $0.20^{\mathrm{H}}$ & $0.30 \mathrm{~b}$ \\
\hline & 'HRS 812' & 2.76 & 3.82 & $0.88 b^{L}$ & 0.40 & 0.08 & 0.16 & $0.30 \mathrm{~b}$ \\
\hline & $\operatorname{Pr}>F$ & 0.36 & 0.39 & 0.05 & 0.52 & 0.09 & 0.12 & 0.035 \\
\hline
\end{tabular}

${ }^{\mathrm{z}} \mathrm{N}=$ nitrogen, $\mathrm{Ca}=$ calcium, $\mathrm{K}=$ potassium, $\mathrm{Mg}=$ magnesium, $\mathrm{Na}=$ sodium, $\mathrm{P}=$ phosphorous, and $\mathrm{S}=$ sulfur. Superscripts $\mathrm{H}=$ high concentration and L = low level based on Florida State guidelines (Obreza et al., 2008).

y Means followed by the same letter or no letters in a column within each scion are not significantly different by Tukey's test at $\alpha<0.05$. 
Leaf tissue B and Fe concentrations varied significantly by rootstock in both orange varieties (Table 3). Tissue collected from both scions on 'Carrizo' had lower B concentrations than those collected from scions on 'HRS 802' or 'HRS 812'. Fe levels were significantly lower in 'HRS 812' tissue samples of both scions. No significant differences were found in tissue concentrations of $\mathrm{Al}, \mathrm{Cu}, \mathrm{Mn}$, and $\mathrm{Zn}$.

Table 3. Mean concentrations of plant micronutrients and trace elements in 2016 of two sweet orange cultivars growing on Alonso clay series soil grafted on three different rootstocks at the Agricultural Experiment Station of Adjuntas, Puerto Rico.

\begin{tabular}{|c|c|c|c|c|c|c|c|}
\hline \multirow[t]{2}{*}{ Scion } & Rootstocks & $\mathrm{Al}^{\mathrm{z}}$ & B & $\mathrm{Cu}$ & Fe & Mn & Zn \\
\hline & & - - - \% - - & \multicolumn{5}{|c|}{$\ldots-\mathrm{mg}^{-1} \ldots \ldots$} \\
\hline \multirow{4}{*}{$\begin{array}{l}\text { 'Marr's } \\
\text { Early' }\end{array}$} & 'Carrizo' & 80.3 & $67.3 \mathrm{~b}^{\mathrm{y}}$ & 11.0 & 360 a Ex & 89.7 & 38.3 \\
\hline & 'HRS 802' & 74.3 & $99.0 \mathrm{a}$ & 8.67 & $296 \mathrm{a}^{\mathrm{Ex}}$ & 107 & 36.3 \\
\hline & 'HRS 812' & 73.3 & $92.3 \mathrm{a}$ & 10.7 & $174 \mathrm{~b}^{\mathrm{H}}$ & 110 & 30.3 \\
\hline & $\operatorname{Pr}>F$ & 0.94 & 0.05 & 0.66 & 0.045 & 0.76 & 0.50 \\
\hline \multirow{4}{*}{ ‘Pera' } & 'Carrizo' & 70.3 & $64.0 \mathrm{~b}$ & 11.3 & $224 \mathrm{a}^{\mathrm{Ex}}$ & 56 & 34.7 \\
\hline & 'HRS 802' & 79.3 & $91.6 \mathrm{a}$ & 8.67 & $236 a^{E x}$ & 100 & 33.0 \\
\hline & 'HRS 812' & 67.0 & $97.0 \mathrm{a}$ & 12.3 & $182 \mathrm{~b}^{\mathrm{H}}$ & 91 & 32.3 \\
\hline & $\operatorname{Pr}>F$ & 0.72 & 0.043 & 0.14 & 0.034 & 0.20 & 0.79 \\
\hline
\end{tabular}

${ }^{\mathrm{z}} \mathrm{Al}=$ aluminum, $\mathrm{Bo}=$ Boron, $\mathrm{Cu}=$ Cooper, $\mathrm{Fe}=$ Iron, $\mathrm{Mn}=$ manganese, and $\mathrm{Zn}=$ zinc. Superscripts $\mathrm{H}=$ high concentration, and Ex = excess concentration based on Florida State guidelines (Obreza et al., 2008). ${ }^{\mathrm{y}}$ Means followed by the same letter or no letters in a column within each scion are not significantly different by Tukey's test at $\alpha<0.05$.

\subsection{Tree Growth, Yield and Fruit Quality}

Significant differences in tree height, diameter, and CV were only observed in 2015 (Table 4). In 2015, trees of both varieties grafted on 'HRS 802' were significantly different height, diameter, and CV than other scion-rootstock combinations. Although, no significant response was observed for the same variables in 2016, or in tree efficiency in 2015-2016 among scion-rootstock permutations. In 2015, 'Marr's Early' trees grafted on 'HRS 802' had higher tree height, diameter, and CV as compared with the other scion-rootstock combinations. While for 'Pera' sweet oranges, larger diameter and CV were also found on trees grafted in 'HRS 802' rootstock versus those 'Carrizo' and 'HRS 812' rootstocks, but no differences were observed between 'HRS 802' and 'HRS 812' in tree height (Table 4).

Table 4. Tree height, area, canopy, and efficiency of two sweet orange cultivars grafted on three different rootstocks growing on Alonso clay series soil at the Agricultural Experiment Substation of Adjuntas, Puerto Rico in 2015-2016.

\begin{tabular}{|c|c|c|c|c|c|c|c|c|c|}
\hline \multirow[t]{2}{*}{ Scion } & \multirow[t]{2}{*}{ Rootstocks } & \multicolumn{2}{|c|}{$\begin{array}{l}\text { Tree Height } \\
-\ldots(\mathrm{m})---\end{array}$} & \multicolumn{2}{|c|}{$\begin{array}{c}\text { Tree Diameter } \\
-\ldots\left(\mathrm{m}^{2}\right)-\ldots\end{array}$} & \multicolumn{2}{|c|}{$\begin{array}{c}\text { Canopy Volume } \\
-\ldots\left(\mathrm{m}^{3}\right)-\ldots\end{array}$} & \multicolumn{2}{|c|}{$\begin{array}{l}\text { Tree Efficiency } \\
- \text {-(Fruits } \mathrm{m}^{-3} \text { )- - }\end{array}$} \\
\hline & & 2015 & 2016 & 2015 & 2016 & 2015 & 2016 & 2015 & 2016 \\
\hline \multirow{4}{*}{$\begin{array}{c}\text { ‘Marr's } \\
\text { Early’ }\end{array}$} & 'Carrizo' & $1.85 \mathrm{~b}^{\mathrm{z}}$ & 2.21 & $5.13 \mathrm{~b}$ & 7.31 & $5.11 \mathrm{~b}$ & 9.61 & 10.6 & 3.20 \\
\hline & 'HRS 802' & $2.61 \mathrm{a}$ & 2.01 & $10.9 \mathrm{a}$ & 8.53 & $14.9 \mathrm{a}$ & 9.00 & 6.63 & 10.0 \\
\hline & 'HRS 812' & $0.97 \mathrm{c}$ & 2.37 & $4.95 \mathrm{~b}$ & 8.60 & $3.22 \mathrm{~b}$ & 12.4 & 11.8 & 3.54 \\
\hline & $\operatorname{Pr}>F$ & 0.0003 & 0.804 & 0.0017 & 0.846 & $<0.0001$ & 0.782 & 0.486 & 0.263 \\
\hline \multirow{4}{*}{ 'Pera' } & 'Carrizo' & $1.64 \mathrm{~b}$ & 2.35 & $3.39 \mathrm{~b}$ & 7.86 & $4.82 \mathrm{~b}$ & 13.9 & 9.13 & 1.83 \\
\hline & 'HRS 802' & $2.78 \mathrm{a}$ & 1.87 & $9.06 \mathrm{a}$ & 6.67 & $13.4 \mathrm{a}$ & 7.45 & 7.25 & 14.3 \\
\hline & 'HRS 812' & $2.10 \mathrm{ab}$ & 2.34 & $5.21 \mathrm{~b}$ & 6.11 & $5.83 \mathrm{~b}$ & 8.10 & 6.86 & 5.25 \\
\hline & $\operatorname{Pr}>F$ & 0.042 & 0.56 & 0.0003 & 0.702 & 0.0013 & 0.115 & 0.79 & 0.10 \\
\hline
\end{tabular}

\footnotetext{
${ }^{\mathrm{z}}$ Means followed by the same letter or no letters in a column within each scion are not significantly different by
} Tukey's test at $\alpha<0.05$.

Between 2014 and 2016, 'Pera' scions grafted on 'HRS 802' had a higher number of fruit than those grafted on 'HRS 812' or 'Carrizo' (Figure 3). Also, a higher fruit number was found with 'Marr's Early' 
grafted on 'HRS 802' compared with the other two combinations in 2014. No differences were found with other 'Marr's Early' rootstock-scion combinations for the other years (Figure 3). Both scions grafted on 'HRS 802' rootstocks in the years 2015-2016 exhibited two-fold differences in total fruit weight per tree compared with the other combinations (Figure 4).
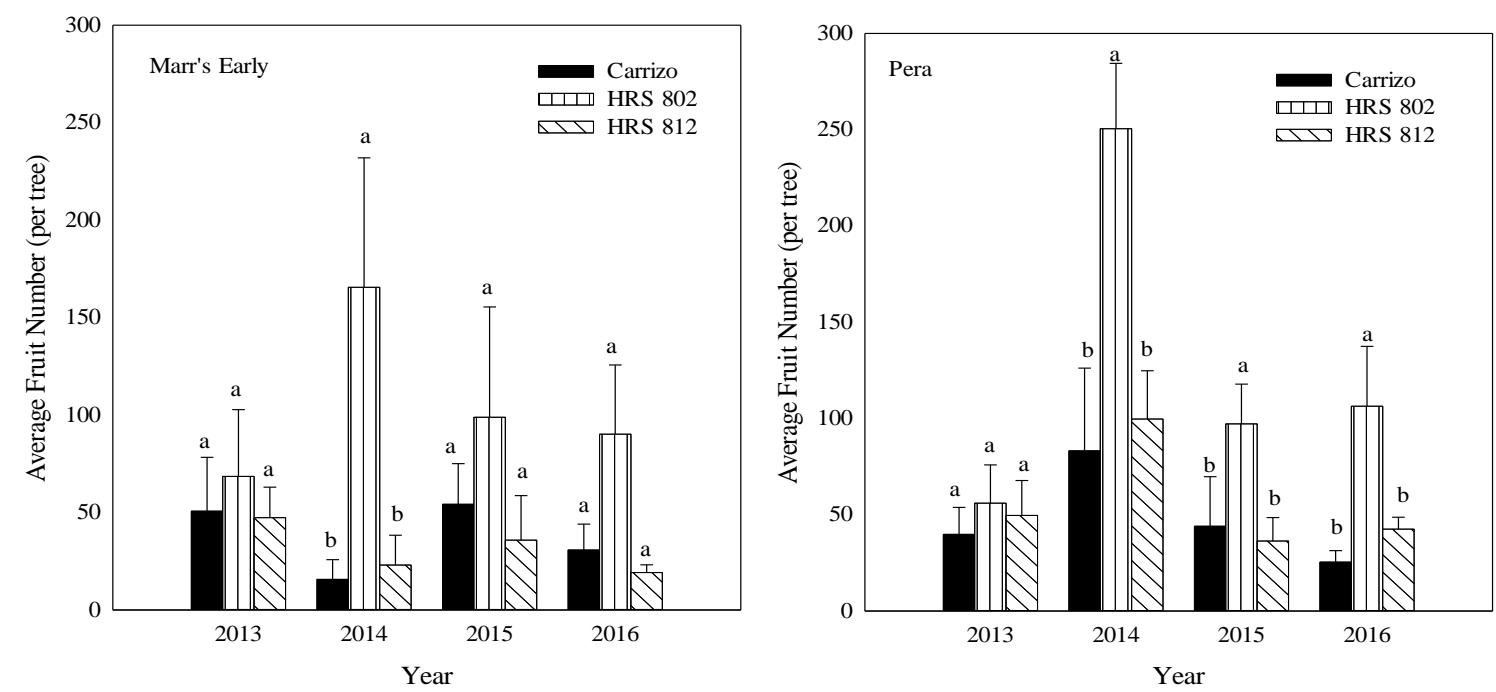

Figure 3. Total average fruit number (2013-2016) of 'Marr's Early' and 'Pera' sweet oranges grafted on three different rootstocks growing in Alonso clay series soil at the Agricultural Experiment Substation of Adjuntas, Puerto Rico. Means \pm standard error with the different letters for each scion and year are not significantly different by Tukey's test at $\alpha<0.05$.
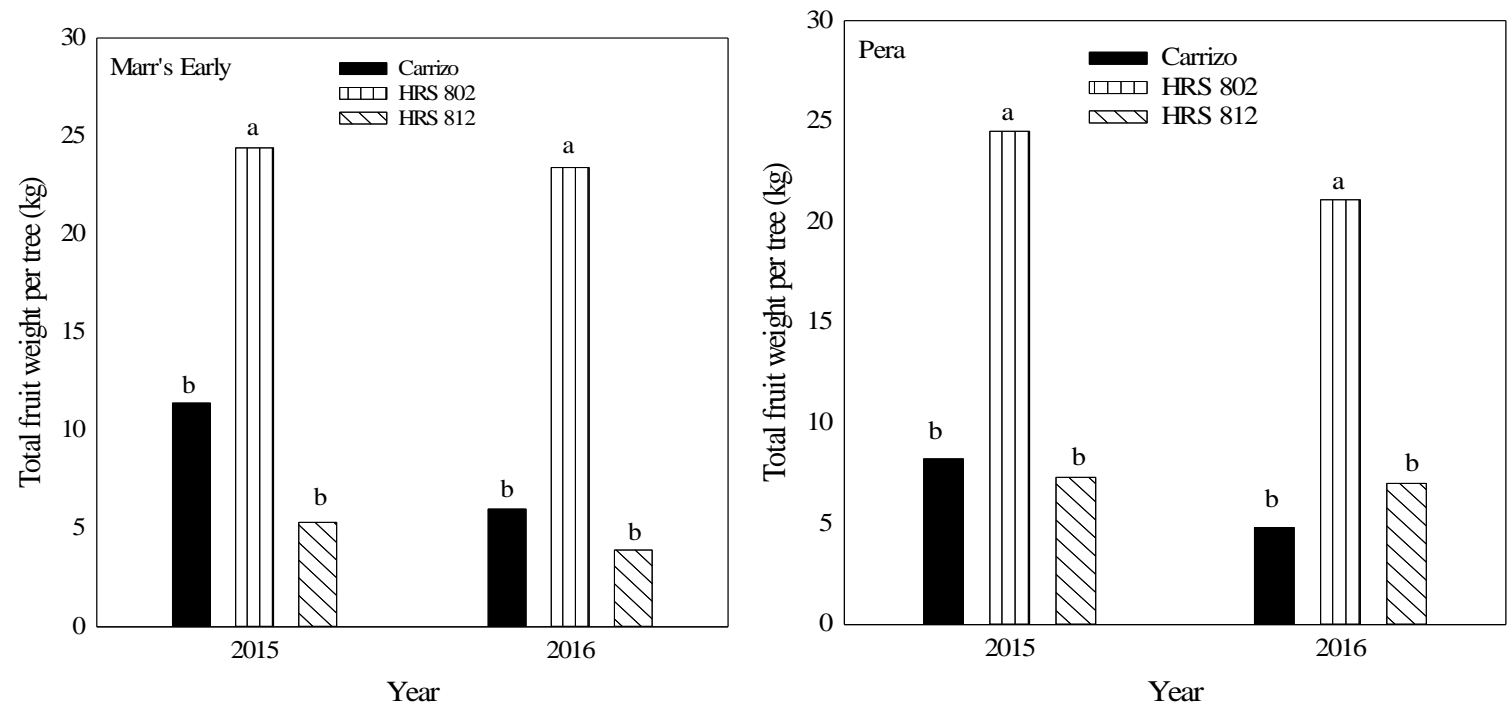

Figure 4. Total fruit weight per tree in 2015 and 2016 of 'Marr's Early' and 'Pera' sweet orange cultivars grafted on three different rootstocks growing on Alonso clay series soil at the Agricultural Experiment Substation of Adjuntas, Puerto Rico. Means with different letters for each scion and year are not significantly different using Tukey's test at $\alpha<0.05$.

\subsection{Fruit Juice Content, Soluble Solids and $\mathrm{pH}$}

Fruit juice content, soluble solids, and $\mathrm{pH}$ results are shown in Table 5. For fruit juice content, both sweet orange cultivars showed statistical differences among rootstocks in 2016, but only 'Marr's Early' did so in 2015. For 'Marr's Early' in 2015, a higher juice percentage was obtained on 'HRS 802' and 'Carrizo' (1.1×) versus 'HRS 812', while in 2016, for both sweet orange cultivars, a higher juice percentage was found for 'HRS 802' versus the other two rootstocks. For soluble solids content, 
statistically, significant differences among rootstocks were found for 'Marr's Early' in 2014 and for 'Pera' in 2015 and 2016. 'Marr's Early' grafted in 'HRS 812' had higher soluble solids content versus 'HRS 802' and 'Carrizo'. While 'Pera' sweet orange had higher soluble solids content on 'Carrizo' in 2015 and on 'HRS 812' in 2016. For both years, lower soluble solids content was found on 'HRS 802' $(\sim 10.3 \%)$ rootstock. A lower $\mathrm{pH}$ was found in 'Marr's Early' grafted on 'HRS 802' rootstock in 2016 and a higher pH in 'Pera' sweet orange was found when grafted on the same rootstock in 2014 and 2015.

Table 5. Juice content, soluble solids, and $\mathrm{pH}$ of the fruit of two sweet orange cultivars grafted on three different rootstocks growing on Alonso clay series soil at the Agricultural Experiment Substation of Adjuntas, Puerto Rico in 2014-2016.

\begin{tabular}{|c|c|c|c|c|c|c|c|c|c|c|}
\hline \multirow[t]{2}{*}{ Scion } & \multirow[t]{2}{*}{ Rootstocks } & \multicolumn{3}{|c|}{$\begin{array}{c}\text { Juice Content } \\
\text { - - -(Juice \%/Weight)- - - }\end{array}$} & \multicolumn{3}{|c|}{$\begin{array}{c}\text { Soluble Solids } \\
\text { - - - - }\left({ }^{\circ} \text { Brix }\right)-\ldots-~-~\end{array}$} & \multicolumn{3}{|c|}{$\mathrm{pH}$} \\
\hline & & 2014 & 2015 & 2016 & 2014 & 2015 & 2016 & 2014 & 2015 & 2016 \\
\hline \multirow{4}{*}{$\begin{array}{r}\text { 'Marr's } \\
\text { Early' }\end{array}$} & 'Carrizo' & 48.7 & $51.3 \mathrm{a}^{\mathrm{z}}$ & $52.0 \mathrm{~b}$ & $12.4 \mathrm{~b}$ & 10.5 & 10.7 & 3.79 & 3.72 & $3.65 \mathrm{a}$ \\
\hline & 'HRS 802' & 47.3 & $51.1 \mathrm{a}$ & $55.0 \mathrm{a}$ & $10.7 \mathrm{~b}$ & 12.2 & 9.6 & 3.61 & 3.61 & $3.53 \mathrm{~b}$ \\
\hline & 'HRS 812' & 45.6 & $48.5 \mathrm{~b}$ & $51.5 \mathrm{~b}$ & $14.5 \mathrm{a}$ & 13.6 & 10.8 & 3.93 & 3.73 & $3.63 \mathrm{a}$ \\
\hline & $\operatorname{Pr}>F$ & 0.25 & 0.04 & 0.001 & 0.002 & 0.19 & 0.22 & 0.24 & 0.19 & 0.01 \\
\hline \multirow{4}{*}{ 'Pera' } & 'Carrizo' & 47.6 & 50.0 & $52.5 \mathrm{~b}$ & 13.9 & $15.4 \mathrm{a}$ & $10.9 \mathrm{~b}$ & $3.51 \mathrm{~b}$ & $3.46 \mathrm{~b}$ & 3.42 \\
\hline & 'HRS 802' & 45.2 & 49.9 & $54.5 \mathrm{a}$ & 11.5 & $10.4 \mathrm{c}$ & $10.1 \mathrm{c}$ & $3.91 \mathrm{a}$ & $3.72 \mathrm{a}$ & 3.51 \\
\hline & 'HRS 812' & 49.3 & 52.0 & $54.0 \mathrm{~b}$ & 12.5 & $11.7 \mathrm{~b}$ & $13.2 \mathrm{a}$ & $3.43 \mathrm{~b}$ & $3.41 \mathrm{~b}$ & 3.49 \\
\hline & $\operatorname{Pr}>F$ & 0.15 & 0.12 & 0.001 & 0.08 & 0.001 & 0.002 & 0.05 & 0.04 & 0.19 \\
\hline
\end{tabular}

${ }^{\mathrm{z}}$ Means followed by the same letter or no letters in a column within each scion are not significantly different by Tukey's test at $\alpha<0.05$.

\section{Discussion}

It is a well-established rule that success in citrus production usually depends on the selection of suitable and high-quality scion-rootstock combinations [7-24]. The use of these scion-rootstock combinations generally results in adaptable and disease tolerant trees capable of growing in a wide range of environmental conditions. Thus, data for rootstock-scion-soil interactions have taken new and unexpected importance since the establishment of HLB in Puerto Rico. Previous work on this subject at the same location was conducted either before the current HLB outbreak, or in coastal or mid-elevation orchards, and thus likely does not reflect the current state of citrus production [25-27].

In other parts of the world, work with rootstock-scion combinations in response to HLB has been extensive. For example, Bowman and Rouse [28] found that 'HRS 812' rootstock was highly productive in Florida, with high-quality fruit and tolerance to CTV. Albrecht and Bowman [29] found in a laboratory trial that 'Carrizo' and 'HRS-897' (also known as US 897) were tolerant to HLB, while 'HRS 812' was considered moderately tolerant when compared to 'Cleopatra' mandarin. Also, in Florida, Stover et al. [30] found that growth and fruit production of the highest performing scion-rootstock combinations was generally less than would be expected for healthy trees, but were nonetheless promising. Still, these authors found markedly better responses of some scion-rootstock combinations, particularly when using mandarin hybrid scions.

It is challenging to interpret our leaf tissue or soil analyses, as there are no local guidelines in Puerto Rico. Most recommendations provided by the Puerto Rico Department of Agriculture (PRDA) or the Agricultural Extension Services (AES) have been based on data and recommendations gathered from citrus growers by the Florida State Cooperative Extension Service publications found in Obreza et al. [31]. Significant differences exist among soil types, topography, and climate between Florida and Puerto Rico, so the inherent limitations of such recommendations are a significant concern. Notwithstanding this, when compared with Florida guidelines by Obreza et al. [31], most leaf sample values obtained in our research were in the optimum range for $\mathrm{Ca}, \mathrm{Mg}, \mathrm{Na}, \mathrm{P}, \mathrm{B}, \mathrm{Cu}$, and $\mathrm{Zn}$. A few sample results were in high (i.e., $\mathrm{N}$ and $\mathrm{P}$ ), but there was no clear connection to specific scions or rootstocks. However, excess Fe concentration was found with 'HRS 802' and 'Carrizo' when compared 
with 'HRS 812', which had a concentration at the high end. However, no negative responses were observed to this excess.

Scientifically-based fertilization data for overcoming the damage caused by HLB is scarce. Accurate HLB detection requires DNA tests since visual symptoms are similar to micronutrient deficiencies and other citrus diseases such as citrus variegated chlorosis. Results from leaf analyses by Spann et al. [32] attributed nutrient deficiencies to HLB, where infected plants had significantly lower values of the macronutrients $\mathrm{Ca}, \mathrm{P}$, and $\mathrm{S}$ and the micronutrients $\mathrm{Mn}, \mathrm{Fe}$, and Cu. Studies by Gottwald et al. [33] indicated no effective response to insecticide application to reduce ACP population, nor to an enhanced nutritional program on two trials conducted with Valencia orange in Florida. In Brazil, even though infected trees were removed, and intensive ACP management practices were performed, HLB disease has spread exponentially, causing significant yield losses [34]. Improved plant nutrition could mitigate the effects of HLB in citrus trees.

Worldwide, the climate change and invasive pest species are key threats to agriculture. Their separate and combined adverse effects are expected to disrupt crop production, to change land-use patterns, and to diminish food security for billions of humans [35-37]. Few examples are as illustrative of these catastrophic disruptions as the introduction of HLB disease in Puerto Rico. Since its detection in the island in 2009 , this lethal disease has been responsible for a $40 \%$ production decline between 2012 and 2015 (i.e., 2,556 tons to 1,557 tons) [5].

Sweet oranges were traditionally grown at all elevations in Puerto Rico, but primarily in the central mountainous region where favorable climatic conditions produced desirable color and flavor. The impact of HLB on Puerto Rico's citrus industry can now be inferred from a finding by Jenkins et al. [8] that indicated that ACP populations declined with elevation, finding no vectors at elevations over $600 \mathrm{~m}$ in Puerto Rico. If this elevation is taken as the "safe line" for citrus production in Puerto Rico, then this means that only $6.4 \%$ of the island is viable for growing citrus. Noteworthy of consideration is that global warming will likely continue to reduce viable citrus production areas even more, as temperature averages will gradually keep increasing with elevation. While the introduction of HLB and its insect vector into Puerto Rico has likely more to do with unchecked market globalization than with climate change, a clear nexus to climate change may now worsen its impact on the island's citrus industry, especially sweet orange production.

Sweet oranges are popular worldwide for fresh consumption and also for processing (i.e., juice, canning). It is a well-established tenet that success in citrus production usually depends on the selection of suitable high-quality scion-rootstock combinations $[7,22]$. The use of these scion-rootstock combinations generally results in adaptable trees, capable of growing in a wide range of environmental conditions, and that are tolerant to various pests and diseases. In terms of fruit production (number and weight per tree) and juice content, both sweet oranges grafted on 'HRS 802' produced more fruit, which had more juice content than when grafted on HRS 812 and Carrizo. This rootstock can be recommended to local farmers growing sweet oranges on Alonso series (Inceptisol Order) soil.

\section{Conclusions}

Both sweet orange cultivars 'Marr's Early and 'Pera' growing on Alonso clay series soil at elevations higher than $600 \mathrm{~m}$ showed benefits in tree growth parameters (i.e., height and diameter), fruit production (number and weight per tree), and juice quantity when grafted on 'HRS 802' compared with those on 'HRS 812' and 'Carrizo' rootstocks. Based on our foliar analysis, most of the nutrients were likely in the optimum range, which means the fertilization program covered the orchard needs growing in the Inceptisol at the higher elevation. Based on our results, we recommend that 'HRS 802' be used by local farmers growing sweet oranges on Alonso series soil.

Author Contributions: R.T.-C., run the statistical analysis of the variables; R.T.-C., D.R.-O. and A.S.-C., wrote the manuscript, M.M.-R., generated the maps, C.E.d.J., run CLas, CTV and CVC analysis of the trees before planting, J.P., took the tree's measurements and harvest the fruits. All the authors revised the manuscript. All authors have read and agreed to the published version of the manuscript. 
Funding: This research was funded with Hatch Regional.

Acknowledgments: The authors will like to thanks HATCH-94Q (Citrus plant production systems, genetic resources, and breeding) for funding this study. In addition, we will like to thanks Jeniffer Pagán, and other personnel from the AES of Adjuntas and Lyvette Trabal-Valentín for helping us with soil and plant sampling and field management.

Conflicts of Interest: The authors declare no conflict of interest.

\section{References}

1. Departamento de Agricultura, División Estadísticas Agrícolas, Estado Libre Asociado de Puerto Rico. Ingreso Bruto Agrícola; Departamento de Agricultura, División Estadísticas Agrícolas, Estado Libre Asociado de Puerto Rico: San Juan, PR, USA, 2015.

2. Arce, S.C.; Rivera, D. New media components and fertilization to accelerate the growth of citrus rootstocks grown in a greenhouse. Horticulturae 2018, 4, 10. [CrossRef]

3. Batool, A.; Iftikhar, Y.; Mughal, S.M.; Khan, M.M.; Jaskani, M.J.; Abbas, M.; Khan, I.A. Citrus greening disease-A major cause of citrus decline in the world-A review. Hortic. Sci. (Prague) 2007, 34, 159-166. [CrossRef]

4. Halbert, S.E.; Núñez, C.A. Distribution of the Asian citrus psyllid, Diaphorina citri Kuwayama (Rhynchota: Psyllidae) in the Caribbean basin. Fla. Entomol. 2004, 87, 401-402. [CrossRef]

5. Méndez, J. Mensaje del Presidente. In Décimo Cuarta Asamblea Annual; Productores de Cítricas de la Montaña, Inc.: Lares, Puerto Rico, 2016.

6. Zamora-Echevarría, J.L. Manejo nutricional del "Citrus greening" y su costo. El Frutal 2013, 9, 1.

7. Castle, W.S.; Baldwin, J.C. Young-Tree performance of juvenile sweet orange scions on Swingle citrumelo rootstocks. HortScience 2011, 46, 541-552. [CrossRef]

8. Jenkins, D.A.; Hall, D.G.; Goenaga, R. Diaphorina citri (Hemiptera: Liviidae) abundance in Puerto Rico declines with elevation. J. Econ. Entomol. 2015, 108, 252-258. [CrossRef] [PubMed]

9. Miller, G.L.; Lugo, A.E. Guide to the Ecological Systems of Puerto Rico; General Technical Report, IITF-GTR-35; United States Department of Agriculture: Washington, DC, USA; Forest Service: Washington, DC, USA; International Institute of Tropical Forestry: San Juan, Puerto Rico, 2009; 444p.

10. Muñoz, M.; Lugo, W.I.; Santiago, C.; Matos, M.; Ríos, S.; Lugo, J. Taxonomic Classification of the Soils of Puerto Rico, 2017; Bulletin 313; University of Puerto Rico, Mayagüez Campus: Mayagüez, Puerto Rico; College of Agricultural Sciences Agricultural Experiment Station: San Juan, Puerto Rico, 2018; 20p.

11. Román-Pérez, F.M.; González-Vélez, A.; Santana, O.; Rodríguez, R. Performance of Chironja (Clon 2-4) on five rootstocks after eight years of growth in two zones in Puerto Rico. J. Agric. Univ. P. R. 2009, 93, 187-193.

12. Yokomi, R.K.; Rivera, D.; Garnsey, S.M.; Gottwald, T.R.; Abreu-Rodriguez, E.; Damsteegt, V.; Stansly, P.A.; Febres, V.J.; Niblett, C.L. Incidence of brown citrus aphid and citrus tristeza virus in Puerto Rico. In Proceedings of the Thirteenth IOCV Conference, 1996-Citrus Tristeza Virus, Fuzhou, China, 16-23 November 1996; pp. 83-91.

13. Rodríguez, R.; Escudero, J.; Rivera, D. Incidencia del virus de la tristeza en fincas productoras de cítricos en Puerto Rico. In Proceedings of the 55th Annual Meeting, Puerto Rican Society of Agricultural Science, Isabela, Puerto Rico, 10 November 1995.

14. Marroquín-Guzmán, M.R. Diseminación del Enverdecimiento de los Cítricos y Evaluación de Protocolos Para la Certificación de Material Propagativo en Puerto Rico. Crop Protection. Master's Thesis, University of Puerto Rico, Mayagüez Campus, Puerto Rico, 2012; 128p.

15. Marroquín-Guzmán, M.R.; Estévez de Jensen, C. Prevalent citrus diseases in Puerto Rico. Abstract $102 S$. In Proceedings of the APS-MSA Joint Meeting, Austin, TX, USA, 10-14 August 2013.

16. Marroquín-Guzmán, M.R.; Estévez de Jensen, C. Dissemination of citrus greening in Puerto Rico. J. Agric. Univ. P. R. 2013, 97, 119-134.

17. Román-Pérez, F.M.; González-Vélez, A. Liberación de los patrones de cítricas "Swingle Citrumelo", "Carrizo" y “HRS 812” para Puerto Rico. J. Agric. Univ. P. R. 2013, 97, 101-106.

18. Jagoueix, S.; Bové, J.M.; Garnier, M. Detection of the two Candidatus Liberibacter species associated with greening disease of citrus. Mol. Cell. Probes 1996, 10, 43-50. [CrossRef] [PubMed] 
19. Thomas, G.W. Soil pH and soil acidity. In Methods of Soil Analysis, Part 3-Chemical Methods; Sparks, D.L., Ed.; Soil Science Society of America: Madison, WI, USA, 1996; pp. 475-490.

20. Warncke, D.; Brown, J.R. Potassium and other basic cations. In Recommended Chemical Soil Test Procedures for North Central Region; NCR Publication No. 221; Missouri Agricultural Station: Columbia, MO, USA, 1998; pp. 31-33.

21. Jackson, M.L. Soil Chemical Analysis; Prentice-Hall: Englewood Cliffs, NJ, USA, 1958.

22. Hossner, L.R. Dissolution for total elemental analysis. In Methods of Soil Analysis, Part 3-Chemical Methods; Sparks, D.L., Ed.; Soil Science Society of America: Madison, WI, USA, 1996; pp. 49-64.

23. Fallahi, E.; Mousavi, Z. Performance of Orlando tangelo trees on ten rootstocks in Arizona. J. Am. Soc. Hortic. Sci. 1991, 116, 2-5. [CrossRef]

24. Castle, W.S.; Tucker, D.P.H.; Krezdorn, A.H.; Youtsey, C.O. Rootstocks for Florida Citrus, 2nd ed.; University of Florida Institute of Food and Agricultural Sciences: Gainesville, FL, USA, 1993; 92p.

25. Román-Pérez, F.M.; González-Vélez, A.; Macchiavelli, R. Efecto de cuatro patrones en la producción y calidad de la china "Hamlin" (Citrus sinensis L. Osb.) en tres localidades de Puerto Rico. J. Agric. Univ. P. R. 2011, 95, 25-34.

26. Román-Pérez, F.M.; González-Vélez, A.; Pagán, J.; Estévez de Jensen, C.; Rosa, E. New Approaches in the Production of Citrus in Puerto Rico; Abstracts; Caribbean Food Crops Society: Saint Thomas, VA, USA, 2014; Volume 50, p. 59.

27. Román-Pérez, F.M.; González-Vélez, A.; Macchiavelli, R.; Estévez de Jensen, C. Comportamiento de la lima Tahití (Citrus latifolia Tan) en cinco patrones y dos zonas productoras de Puerto Rico. J. Agric. Univ. P. R. 2017, 101, 225-236.

28. Bowman, K.D.; Rouse, R.E. US-812 citrus rootstock. HortScience 2006, 41, 832-836. [CrossRef]

29. Albrecht, U.; Bowman, K.D. Tolerance of trifoliate citrus hybrids to Candidatus Liberibacter asiaticus. Sci. Hortic. 2012, 147, 71-80. [CrossRef]

30. Stover, E.; Inch, S.; Richardson, M.L.; Hall, D.G. Conventional citrus of some scion/rootstock combinations show field tolerance under high Huanglongbing disease pressure. HortScience 2016, 51, 127-132. [CrossRef]

31. Obreza, T.A.; Zekri, M.; Futch, S.H. General soil fertility and citrus tree nutrition. In Nutrition of Florida Citrus Trees, 2nd ed.; Obreza, T.A., Morgan, K.T., Eds.; IFAS Extension Document SL 253; University of Florida: Gainesville, FL, USA, 2008; 100p.

32. Spann, T.M.; Atwood, R.A.; Yates, J.D.; Rogers, M.E.; Brlansky, R.H. Dooryard Citrus Production: Citrus Greening Disease; EDIS HS1131; University of Florida, Institute of Food and Agricultural Sciences: Gainesville, FL, USA, 2010.

33. Gottwald, T.R.; Graham, J.H.; Irey, M.S.; Mc Collum, T.G.; Wood, B.W. Inconsequential effect of nutritional treatments on Huanglongbing control, fruit quality, bacterial titer and disease progress. Crop Prot. 2012, 36, 73-82. [CrossRef]

34. Morris, A.; Muraro, R. Economic Evaluation of Citrus Greening Management and Control Strategies; EDIS Doc. FE712; University of Florida, Florida Cooperative Extension Service: Gainesville, FL, USA, 2008; 7p.

35. Parry, M.L. Climate Change and World Agriculture; Earthscan Publications Limited: London, UK; International Institute for Applied Systems Analysis: Laxenburg, Austria; United Nations Environment Programme: Nairobi, Kenya, 1990.

36. Schlenker, W.; Lobell, D.B. Robust negative impacts of climate change on African agriculture. Environ. Res. Lett. 2010, 5, 1. [CrossRef]

37. Ziska, L.H.; Blumenthal, D.M.; Brett Runion, G.; Hunt, E.R., Jr.; Diaz-Soltero, H. Invasive species and climate change: An agronomic perspective. Clim. Chang. 2011, 5, 13-42. [CrossRef]

(C) 2020 by the authors. Licensee MDPI, Basel, Switzerland. This article is an open access article distributed under the terms and conditions of the Creative Commons Attribution (CC BY) license (http://creativecommons.org/licenses/by/4.0/). 